\title{
Review on Goat Milk Composition and its Nutritive Value
}

\author{
Getaneh $\mathrm{G}^{*}$, Mebrat A, Wubie A and Kendie H
}

University of Gondar, Faculty of Veterinary Medicine, Unit of Biomedical Science, Ethiopia

${ }^{*}$ Corresponding author: Getaneh G, University of Gondar, Faculty of Veterinary Medicine, Unit of Biomedical

Science, Ethiopia, E-mail: gashaw296@gmaiil.com

Citation: Getaneh G, Mebrat A, Wubie A, Kendie H (2016) Review on Goat Milk Composition and Its

Nutritive Value. J Nutr Health Sci 3(4): 401. doi: 10.15744/2393-9060.3.401

Received Date: August 19, 2016 Accepted Date: November 21, 2016 Published Date: November 23, 2016

\begin{abstract}
Goat milk is an important nutrient for humans, especially who have problem of lactose intolerance and sensitive to other animals' milk. Goat milk is composed of different usable nutrients which are important to their young and humans. Among those important nutrients that are found in goat milk are fat, protein, lactose, vitamins, enzymes and mineral salts. Most of the components of goat milk are greater than that of other milk producing animals. For instance, goat's milk contains $25 \%$ more vitamin B6, 47\% more vitamin A and $13 \%$ more calcium than cow's milk. However, available information concerning goat milk is mainly limited to data on its gross composition, and information on the nutritional quality of goat milk, especially important nutritional constituents are scarce. In addition, cultural beliefs challenge the reputation of the advantage of goat milk consumption and the development of the sector, especially in developing countries. Knowledge about the nature of goat milk is important to investigate the use of the goat milk to humans. Moreover, goat milk is also used as therapy against different problems including gastrointestinal disturbances, vomiting, colic, diarrhea, constipation and respiratory problems.
\end{abstract}

Keywords: Composition; Goat; Milk and Nutritive value

\section{Introduction}

There are nearly 500 breeds of goats in the world; however, only a half dozen are generally raised for their milk purpose and about 600-700 million of dairy goats are present in the world [1]. They are living in climates ranging from high altitude mountains to deserts [2]. More than $95 \%$ of the goat population is found in developing countries. Worldwide trends of the evolution of the goat population and their products between 1969 and 2010 show a continuous and rapid increase relative to either cattle or sheep, especially in the developing countries [3]. The major species of dairy goats are Anglo-nubian, British alpine, Toggenburg and Saanen. Toggenburg is the best breed that can produce a lot of milk; it is not uncommon to find a two gallon (7.57 liters) milk per day [4].

In Ethiopia goats are raised mainly for three purposes; about 3\% of adult goats are kept for milk, about 3.36\% for meat, about $46.3 \%$ for breeding, and the rest are raised for all the above three and other purposes [5]. According to CSA (2008-2010), there are about 21.96 million goats in Ethiopia.

Due to rapidly increasing human population, the demand for milk and milk products is on the rise in the tropical developing countries. The increased demand can be met by increasing ruminant livestock population as suggested by [6]. The contribution of small ruminants in general and goats in particular in meeting this demand will be very high. Goats are important milk producers in several parts of the tropics and contribute significantly to human nutrition in many developing countries [7].

One of the most important contributions of goat milk to human nutrition is the calcium and phosphate that it supplies. Goat milk contains about $1.2 \mathrm{~g}$ calcium and $1 \mathrm{~g}$ phosphate per litre; these concentrations are similar to those in cow milk [8]. Human milk contains much less of these minerals with only one-fourth as much calcium and one-sixth as much phosphate. Thus goat milk provides a great excess of $\mathrm{Ca}$ and $\mathrm{P}$ in relation to energy to human infant, both calcium and phosphorus of goat milk are absorbed by the human infant [8]. The soft curd of goat milk may be an advantage for adult humans suffering from gastrointestinal disturbances and ulcers [9]. High buffering capacity of goat milk appears to be useful for treatment of gastric ulcers [10]. Goat milk has been recommended as a substitute for patients allergic to cow milk. Between 40-100\% of patients allergic to cow milk proteins tolerate goat milk [10]. Medium chain length fatty acid or Medium Chain Triglycerides (MCT) which are more in goat milk have been recognized as unique lipid with unique health benefits in mal-absorption syndromes, chyluria, steatorrhea, hyperlipoproteinnemia, and in cases of intestinal resection, coronary bypass, premature infant feeding, childhood epilepsy and gallstones. MCT also inhibits or limits cholesterol deposition, dissolve cholesterol gallstones and contributes to normal growth of infants [11]. 
The gross composition of goat milk is higher than that in bovine milk, except for lactose which is low. Fat globules are smaller and probably one of the reasons for easy digestion of this milk. Its products are high source of protein, fat, phosphate and calcium. Its composition varies with factors such as diet, breed, environment, and management [12].

Goat's milk is the most complete food known which is highly compatible and nourishing natural food. So it is highly nutritious that it can actually serve as a substitute for a meal. It is also preferred due to its low fat content and its capability to neutralize the acids and toxins present in the body (http://www.roseofsharonacres.com/raw_goat_milk_benefits).

It differs from cow or human milk in higher digestibility, distinct alkalinity, higher buffering capacity, and certain therapeutic values in medicine and human nutrition. The nutritional and health benefits of goat milk are related to a number of medical problems, foremost being food allergies and also a substitute for those who suffer from cow milk allergy [13].

The natural homogenization of goat milk is, from a human health standpoint, much better than the mechanically homogenized cow milk product. It appears that when fat globules are forcibly broken up by mechanical means, it allows an enzyme associated with milk fat, known as xanthine oxidase to become free and penetrate the intestinal wall. Once xanthine oxidase gets through the intestinal wall and into the bloodstream, it is capable of creating scar damage to the heart and arteries, which in turn may stimulate the body to release cholestrol into the blood in an attempt to lay a protective fatty material on the scarred areas. This can lead to arteriosclerosis. It should be noted that this effect is not a problem with natural (unhomogenized) cow milk. In unhomogenized milk this enzyme is normally excreted from the body without much absorption [14].

One of the more significant differences from cow milk is found in the composition and structure of fat in goat milk. The average size of goat milk fat globules is about 2 micrometers, as compared to 21/2 - 31/2 micrometers for cow milk fat. These smaller sized fat globules provide a better dispersion, and a more homogeneous mixture of fat in the milk. Research indicates that there is more involved to the creaming ability of milk than merely physical size of the fat globules. It appears that their clustering is favored by the presence of an agglutinin in milk which is lacking in goat milk, therefore creating a poor creaming ability, especially at lower temperatures (http://www.redwoodhill.com/artisan-cheese/).

There are various factors that affect the content of the goat's milk. These factors are including breed, stage of lactation, season of kidding, species, individual animals, age and parity, colostrums, feed (diet), environment (temperature and humidity, length of dry period and gestation, disease and body weight [15].

Therefore, this paper was embodied with the following objectives:

- To discuss the composition and nutritive value of goat milk

- To explain the potential influencing factors on goat milk production and composition

- To increase awareness of the nutritive and medicinal value of goat milk

\section{Goat Milk Production}

Nowadays, $65 \%-72 \%$ of the world's population drinks goat's milk. In many countries in the world, goat's milk is preferred to cow's milk. Goats are naturally immune to diseases, such as tuberculosis, and are used in some countries to actually cure tuberculosis because of their inherent antibodies (http://www.nourishingourchildren.wordpress.com/2012/06/11/got-goat-milk/) (Table 1).

\begin{tabular}{|c|c|}
\hline Country & Milk production (1000 tons) \\
\hline \multicolumn{2}{|c|}{ Africa } \\
\hline Ethiopia & 50,501 \\
\hline Mali & 223,818 \\
\hline Sudan & $1,475,000$ \\
\hline \multicolumn{2}{|c|}{ Asia } \\
\hline India & $4,114,290$ \\
\hline Bangladesh & $2,226,900$ \\
\hline Pakistan & 719,000 \\
\hline \multicolumn{2}{|c|}{ Europe } \\
\hline France & 623,460 \\
\hline Greece & 484,000 \\
\hline Spain & 473,000 \\
\hline \multicolumn{2}{|c|}{ Americas } \\
\hline Mexico & 169,698 \\
\hline Brazil & 143,768 \\
\hline World & $15,510,411$ tone's per year \\
\hline
\end{tabular}




\section{Lactation}

Lactation is the secretion or formation of milk, the time during at which a doe produces milk. Depending on the breed and the environmental condition, the length of lactation varies from 200-350 days. A normal termination of lactation considered to be 305 days [16].

\section{Milk yield}

Nondairy breeds of goats in the tropics have daily milk yield up to 0.5 liters while specialized dairy goat breeds, including the Nubian, Saanen, Alpine, LaMancha and Toggenburg, could give 2-4 liters per day [17].

Goat milk products are; goat cheese, flavored goat milk powder, goat milk yoghurt, goat milk colostrums, goat milk powder for pets, pasteurized goat milk, yoghurt and bottled juice of milk [18].

\section{Milking frequency}

Milking is the act of removing milk from the udder. Goats should be milked twice a day on a regular schedule, preferably every 12 hours. A reduction in the number of times a goat is milked per day will reduce milk yield. If goats are only milked once a day, then yield will be reduced by one third [19].

\section{Factors that affect goat milk production}

There are various factors that affect milk production including body size and weight, age, udder size and shape, growth, litter size, season of kidding, nutrition, temperature, disease and breed [17].

Body size and weight: There is positive relationship between body weight and milk yield. Larger does produce more milk, but research indicates that only about $10 \%$ of the variation in milk yield can be accounted for body weight [17].

Age: Age affects milk yield, but it is closely to body weight. Age accounts for much of the increase in body weight. Peak milk yield is reached when the doe is between four and eight years age [17].

Udder size and shape: A weak udder attachment is considered a major defect, but udder volume is highly correlated with milk yield (i.e. the larger the udder the greater the milk yield) [20].

Growth: There is tendency for late maturing animals, with a flat growth curve, to be more productive [21].

Litter size: The result of a number of studies indicate that mammary growth during pregnancy. This seems to be reasonable that more milk is needed [22].

Season of kidding: To some extent, the season of kidding influences milk yield. Yield from lactation beginning early in the year (January, February and March) are lower than those beginning later in the year (October, November and December) [23].

Nutrition: The mammary gland needs glucose to form lactose, which in turn largely controls the movement of water in to milk. A reduction in feed intake quickly lowers the milk yield, since there is very little glucose stored in the body [10].

Temperature: Exposure of lactating goats to cold reduce milk secretion. For example, one study showed that the milk yield at 31 ${ }^{\circ} \mathrm{F}\left(-0.5^{\circ} \mathrm{C}\right)$ was about $30 \%$ below that obtained from goats in an environmental temperature of $68^{\circ} \mathrm{F}\left(20^{\circ} \mathrm{C}\right)[24]$.

Disease: It is obvious that the disease lowers milk production, with the degree of the effect determined by the kind and severity of the specific disease. Subclinical diseases are more dangerous on goat milk yield than clinical ones [23].

Breed: European breeds of dairy goats generally have a far higher potential for milk production than indigenous breeds that have not been selected for this attribute $[10,25]$.

\section{Composition of Goat Milk}

The composition of milk varies from goat to goat and differs for the various breeds. The primary importance is for young goat, and especially for man, who drinks the milk, is the composition (http://www.drinc.ucdavis.edu/goat1.htm). These compositions of the milk are discussed below:

\section{Fat}

Fats in milk are called butterfat and occur as suspended globules, which are easily seen via low power microscopes. Goat's milk derives many of its most distinctive properties from its lipid fraction. The average total fat content in the milk is similar to that found in other ruminant species, despite reports that the percentage of fat in goat's milk exceeds that of the cow. Such a controversy most likely derived from the fact that the average percentage of milk fat, as with cow's milk fat, is a variable component, often ranging between 3.0 and 6.0 percent. There are also distinct breed differences in fat composition. It should be remembered, however, the quality and quantity of feeds, genetics season, stage of lactation, etc all influence the average percentage of goat milk 
fat. In terms of cholesterol, goat's milk appears to offer a specific distinction in comparison to cow's milk, cow's milk typically contains about 14 to $17 \mathrm{mg}$ cholesterol per $100 \mathrm{~g}$ milk, while goat's milk is more usually recorded at 11 to $25 \mathrm{mg}$ per 100 gram of milk [26].

\section{Protein}

The relative percentage of protein is similar in both the cow and the goat despite past assertions that the protein content of goat's milk is lower. This variation in range is due to in part to a lack of standardization of protein testing procedures as well as the wide differences encountered among animals accepted as the same breed and interbreed differences [27].

The quantity and distribution of amino acids in the casein fractions of the milk of the two species are similar; the sequence of assembly is almost certainly different. A similar difference appears to be found in the lactalbumin portion as well, with perhaps more clinical significance. The lactalbumin of bovine milk elicits an allergic response from many individuals, a serious problem, especially for young children. These individuals are often able to consume the milk of goats without suffering that reaction, an effect attributed to the dissimilarities in structure of the two proteins [28].

\section{Vitamins}

Goat's milk differs from cow's milk in its much lower content of B1 (thiamine). The meaning of this difference is not entirely clear. It is remarkable that caprine milk derives its vitamin A potency entirely from the vitamin itself and entirely lacks the precursor carotenoid pigments characteristic of bovine milk, which also causes goat's milk and milk fat to be much whiter in color than the milk of the cow due to higher casein content. It typically contains $25 \%$ more vitamin B6, $47 \%$ more vitamin A than regular cow's milk, and is mainly contains vit A2 [27].

\section{Lactose}

Lactose is the major free carbohydrate that has been identified in the milk of the goat, though small amounts of inositol are also found. The lactose concentration is usually found to be lower than that found in cow's milk, but the magnitude of the difference is hard to quantify because of the variation in methods of analysis employed. An agreement has not been developed on whether to analyze for lactose in the non-hydrated form or the mono-hydrated form, and this water of hydration is capable of introducing a five percent variation in the reported concentration of the same actual amount of lactose [26].

\section{Mineral salt}

A natural minerals nutrition program that includes goat milk can bring excellent health benefits. The milk contains major and trace minerals including $\mathrm{Ca}, \mathrm{Na}, \mathrm{Mg}, \mathrm{P}, \mathrm{K}$ and $\mathrm{Zn}, \mathrm{Mn}, \mathrm{Se}, \mathrm{Co}, \mathrm{Cu}, \mathrm{Fe}$ respectively. For instance, the milk is a good source of calcium, containing approximately $13 \%$ more calcium per serving than cow's milk, and making it one of the predominant natural minerals in milk and containing about $134 \%$ more K element [29].

\section{Enzymes}

The enzymes of the milk of the goat are similar to those of the cow, although some specific differences have been described. Of primary interest, it has been shown that the level of alkaline phosphatase is slightly lower than that found in the dairy cattle, but the enzyme demonstrates the same degree of heat susceptibility and therefore serves equally as well as a pasteurization marker. Peroxidase activity in the milk of both species is the same in all respects, while the xanthine oxidase level is lower in the milk of the goat. Higher levels of activity are observed for both ribonuclease and lysozyme [27] (Table 2).

\begin{tabular}{|c|c|c|c|}
\hline Composition & Goat (\%) & Cow (\%) & Sheep (\%) \\
\hline Total solid & 13.9 & 13.5 & 19.3 \\
\hline Fat & 4.8 & 4.8 & 7.6 \\
\hline Protein & 3.7 & 2.8 & 5.5 \\
\hline Lactose & 5.0 & 4.5 & - \\
\hline Ash (minerals) & 0.85 & 0.74 & - \\
\hline \multicolumn{4}{|l}{ Source: [6] } \\
Table 2: Composition of goat, cow and sheep milk
\end{tabular}

\section{Factors that Cause Variation in Goat Milk Content}

According to Malau-Aduli BS, et al. goat milk yield and composition are affected by different factors, including breed, age, stage of lactation, season, plane of nutrition and the like.

\section{Genetics}

Goat milk composition can have great differences depending on breed; for example, milk fat from 2.3 percent to 6.9 percent and an 
average of 3.3 percent; milk protein from 2.2 percent to 5.1 percent and an average of 3.4 percent. A major portion of this variation includes negative correlations between milk yield and composition (i.e. low yields have higher contents and vice versa). Some goat milk has low casein contents and unsatisfactory rennet coagulation ability, which affects cheese yield [30].

European breeds of dairy goats generally have a far higher potential for milk production than indigenous breeds that have not been selected for this attribute. This difference applies even when account is taken of the generally higher solids content of the milk of indigenous goats [31].

Inbreeding is generally undesirable for the improvement of many traits because of the effects of homozygosity in allowing the expression of undesirable genes, resulting in inbreeding depression. This is usually greatest for characters associated with natural fitness such as viability and reproductive ability [32].

Crossbreeding results in heterosis (hybrid vigour) for certain characteristics. It is apparent when the average performance of crossbred progeny is superior to the average performance of the two parents. If this is a significant effect, the benefits may not persist with subsequent crossings or grading-up [31].

Artificial insemination technology is now established for goats and can be expected to be used more widely in future. However, the value is limited for identifying outstanding sires, and by the generally small size of dairy goat herds [33].

\section{Stage of lactation}

Within species and breed it affects the milk contents regardless of species or breed that has the greatest influence on milk composition. Many components goat's milk as in cow's milk, especially fat and protein, are high in colostrums in early lactation, much lower thereafter until they rise again markedly at the end of lactation, when yields are low [34].

\section{Daily variation}

Between morning and evening milking on the same day the gross composition of milk may also change, which again may be confounded with milk yield. For instance, fat contents of evening goat milk averaged 5.1 percent after 14 hours of milking interval, morning milk 5.3 percent after 10 hours, total protein contents were 3.54 percent versus 3.58 percent, and total solids were 13.94 percent versus 14.30 percent, respectively [35].

\section{Season}

There are also clear seasonal differences in milk composition of the major and minor components, but they are confounded with climate and diet effects. Winter climate can affect milk yields and composition, and both are negatively correlated. Winter feeding is providing usually different proportions and qualities of grazing, hays, silage and supplements, which influence milk composition considerably [12].

\section{Parity}

Differences due to parity, number of lactation or age of animal can be significant in gross milk composition, but this is also confounded with milk yield levels [22].

\section{Type of diet}

Regardless of genetics, the composition of the daily diet and its amount in relation to production requirements can cause significant changes in milk composition [36,37].

\section{Udder health}

A widely accepted rapid monitor of udder health is the somatic cell count in milk. However, milk secretion in goats is apocrine, while in cows it is merocrine, which explains why goat milk may have very high counts of somatic cells, especially in late lactation milk or in the last strippings of milk, without any relationship to mastitis $[38,39]$.

\section{Processing}

Processing also changes the composition of the milk. Even before cheese precipitation from milk and the effects of fermenting of cheese, the various methods of processing, heating and freezing can have profound influences on milk composition. Heating is applied during pasteurization, UHT processing, condensing and powder production, which will denature milk proteins to varying degrees and affect flavors [40].

\section{Comparative nutritional adequacy}

When milk is consumed as it becomes available from the animal or if its composition is changed in production and processing, a principal question in the pediatric and popular literature is how adequate is that milk for infant or general human needs [40-42]. 


\section{Physiological factors}

Many physiological factors can affect milk contents. Among these physiological factors age, seasonal influence and multiple birth are common.

Age: Age is closely related to body size and parity (lactation number) as it affects milk production. Body mass may increase up to six years of age and decrease thereafter, and milk yield varies similarly, with peak milk yield at between four and eight years. In the work done on Alpine goats it has been found that the highest yields (960 kg) in second lactations, and the lowest (634 $\mathrm{kg}$ ) in seventh lactations [43].

Seasonal influence: Season of kidding can affect milk production and is often confounded with age effects. Extremely cold weather can reduce milk production [44]. Goats producing milk are susceptible to heat stress in spite of heat resistant characteristics [45].

Multiple births: Mammary growth during gestation is said to be affected by the number of kids, and this has a subsequent effect on milk production which is independent of age, body mass and season. Milk production may also be increased in response to suckling stimuli, but this is not a factor in dairy goats if the kids are taken away and fed by hand [44].

\section{Nutritional Value of Goat Milk}

Although the production volume of goat milk is relatively small in total world milk supply, goat keeping has a significant economic importance in countries where climatic conditions are not favorable for cattle raising [46,47].

Goat's milk is the most complete food known which is highly compatible and nourishing natural food. It is so highly nutritious that it can actually serve as a substitute for a meal. It is also preferred due to its low fat content and its capability to neutralize the acids and toxins present in the body. Cow milk is mucus forming for many people; however, goat milk is not only non-mucus forming, but actually helps to neutralize mucus. It is known for its superior in calcium content, in comparison with other animals' milk and the healing enzymes present in it (http://www.roseofsharonacres.com/raw_goat_milk_benefits).

Children with problems digesting cow's milk may have a viable alternative in raw goat's milk which is the second best food option, first being mother's milk, that can consume comfortably, even if they are sensitive to cow or other animals milk. In fact, goat's milk is very similar to human milk, children who drink goat's milk tend to remain more satisfied between meals and sleep through the night [47].

Beyond meeting daily nutrient requirements, it is of special interest that goat milk has unique properties, which distinguish from cow's milk and make them a valuable alternative not just for infants, but also for adults and especially nursing mothers [48].

The milk contains vitamins, minerals, electrolytes, trace elements, enzymes, protein, fatty acids and amino acids (especially tryptophan) that are utilized by human body with ease. Perhaps the greatest benefit of goat's milk, however, is that some people who cannot tolerate cow's milk are able to drink goat's milk without any problems. It is not clear from scientific research studies exactly why some people can better tolerate goat's milk; perhaps due to lower in lactose content (7\% less from cow milk). In fact, our body can digest goat's milk just in 20 minutes while cow's milk takes 2-3 hours [47].

The vitamin and mineral content of goat's milk and cow's milk are fairly similar, though goat's milk contains a bit more calcium, vitamin B6, vitamin A, potassium, niacin, copper and the antioxidant selenium. On the other hand, cow's milk contains more vitamin B12 and much more folic acid. Since goat's milk contains less than ten percent of the amount of folic acid contained in cow's milk, it must be supplemented with folic acid. For this reason, be sure you get a goat's milk that is supplemented with folic acid, which the best brands usually are. Generally, the American Academy of Pediatrics does not recommend the use of goat's milk products in infants under one year because they can cause intestinal irritation and anemia. Infants under one year of age who are allergic to cow's milk-based formulas, soy formulas or hypoallergenic formulas are sometimes put on goat's milk formula, but only with consultation from baby's doctor or a pediatric nutritionist [49].

Glycerol ethers are much higher in goat than in cow milk which appears to be important for the nutrition of the nursing newborn. Goat milk also has lower contents of orotic acid which can be significant in the prevention of fatty liver syndrome. However, the membranes around fat globules in goat milk are more fragile which may be related to their greater susceptibility to develop offflavors than cow milk [14] (Table 3 and 4).

- Most of the world's population drinks goat milk.

- Goat milk is more digestible because the fat molecules are a smaller size than those from cow milk - making it easily tolerated by those with compromised digestive systems.

- Goat milk has less cream separation because of smaller fat molecules.

- Goat milk contains the precursor to vitamin A in the milk fat that allows it to be readily available for use by the body.

- Goat milk is closer to human milk and is more easily accepted especially by those young or frail.

- Goat milk does not form mucous (phlegm) and is better tolerated by asthmatics and those with allergies.

- Goat milk contains more chlorine, fluorine, and silicon than any other domestic livestock. Chlorine and fluorine are natural 
germicides and fluorine assists in preventing diabetes.

- Goat milk contains $2 \%$ curd, which precipitates in the stomach. Cow milk is $10 \%$ curd.

- Goat milk is tolerated by a compromised/damaged liver because of the smaller fat molecules.

Source: Natures Prescription Milk by Gloria Gilbere, N.D., D.A. Hom., PhD

\begin{tabular}{|c|c|c|c|}
\hline Nutrient & Goat milk (\%) & Cow milk (\%) & Human milk (\%) \\
\hline Fat & 3.80 & 3.67 & 4.00 \\
\hline Solid not fat & 8.68 & 9.02 & 8.90 \\
\hline Lactose & 4.08 & 4.78 & 6.92 \\
\hline Total nitrogen & 3.33 & 3.42 & 1.22 \\
\hline Total protein & 2.90 & 3.23 & 1.10 \\
\hline Casein & 2.47 & 2.63 & 0.40 \\
\hline Vit A (IU/gram fat) & 39.0 & 21.0 & 31.9 \\
\hline Vit B ( $\mathrm{gg} / 100 \mathrm{ml})$ & 68.0 & 45.0 & 17.0 \\
\hline Vit C (mg ascorbic & 2.00 & 2.00 & 3.60 \\
\hline acid/100ml) & 0.70 & 0.70 & 0.27 \\
\hline Vit D (IU /gram fat) & & & \\
\hline
\end{tabular}

Source: www.nafis.go.ke/livestock/dairy-goat.../nutritive-value-of-goat-milk/

Table 3: Average composition of goat, cow and human milk

\begin{tabular}{|c|c|c|c|c|c|}
\hline Breed & Height (inch) & Weight (lb) & MY (lb) & Fat (\%) & Protein (\%) \\
\hline Alpine & 30 & 135 & 1990 & 3.56 & 3.06 \\
\hline LaMancha & 28 & 130 & 1712 & 3.80 & 3.29 \\
\hline Nubian & 30 & 135 & 1572 & 4.61 & 3.66 \\
\hline Saanen & 30 & 135 & 2077 & 3.52 & 3.02 \\
\hline Toggenburg & 26 & 120 & 1915 & 3.35 & 3.01 \\
\hline
\end{tabular}

Table 4: Average size, milk yield (MY) and composition of dairy goat breeds [50]

\section{Additional Uses of Goat Milk}

\section{Medicinal value of milk}

The symptoms like gastrointestinal disturbances, vomiting, colic, diarrhoea, constipation and respiratory problems can be eliminated when goat milk is fed to the infants. Pasteurized goat milk is well tolerated by the infants with gastro intestinal or respiratory symptoms. Fermented milk forms a soft curd when compared to cow's milk and hence helps in easy digestion and absorption. Regular intake of goat milk significantly improves the body weight gain, improved mineralization of skeleton, increased blood serum vitamin, mineral and haemoglobin levels [13].

Goats' milk is a good source of $\mathrm{K}$, an essential mineral for maintaining normal blood pressure and heart function. Since a cup of goat's milk contains $498.7 \mathrm{mg}$ of $\mathrm{K}$ and $121.5 \mathrm{mg}$ of $\mathrm{Na}$, hence it helps to prevent high blood pressure and protect against atherosclerosis. It is also a good source of protein, phosphorus, riboflavin (vitamin B2) and potassium (http://goodoledays. weebly. com/benefits-of-goats-milk.html).

An important component present in goat's milk is called biorganic sodium. One of the highest sources of biorganic sodium is goat's milk. Arthritis is thought to be caused by lack of this mineral. The human stomach stores more sodium than any other organ. Therefore, at least some digestive disturbances are thought to be caused by lack of biorganic sodium. The lack of this mineral inhibits the stomach's production of needed enzymes. This in turn causes bloating, and even ulcers. The typical American diet of processed foods, sodas, sugar, and alcohol greatly depletes the body of biorganic sodium (http://www.goodoledays.weebly.com/ benefits-of-goats-milk.html).

Lipids: The qualities regarding lipids in the composition of goat milk fat are very significant at differentiating the special health qualities of goat milk. These are the fat globule size, and the percentages of medium chain fatty acids (http://www.everything-goatmilk.com/milk-fat.html).

Fat globules in goat milk are smaller than in cow's milk. This smaller size, combined with the lack of agglutinin, a protein that causes fat molecules to clump together, and which is present in cow's milk, has several implications. It is theorized that the smaller fat globule size, combined with the fact that the globules do not clump together as in cow's milk, also contribute to the higher digestibility of goat milk, and the better tolerance of it for individuals with certain digestive disorders (http://www.global healingcenter.com/natural-health/goat-milk-benefits/). 
One of the most important components of goat milk in terms of proven health benefits is the percentage of medium chain fatty acids. The first three of these Medium Chain Triglycerides (MCT), 6:0, 8:0 and 10:0 are known as caproic, caprylic and capric acid, respectively. These three fatty acids comprise $15 \%$ of the total of goat milk fat, versus only $5 \%$ for cow's milk. It is also these three compounds that give improperly handled goat milk its characteristic off-taste and smell. As a whole, goat milk has about twice the MCT as cow's milk 35\% compared to $17 \%$ (http://www.goodoledays.weebly.com/benefits-of-goats milk.html).

MCT have the triple effects on the human health; a) lowering cholesterol deposition in the arteries, and b) dissolving and preventing cholesterol deposits in the gallstones. The health benefits of MCT are widely known by the medical community, which uses them as treatment for a variety of conditions including malabsorption syndrome, coronary diseases, cystic fibrosis, intestinal disorders, pre-mature infant nutrition, gallstones, steatorrhoea, chyluria, hyperlipoproteinaemia, childhood epilepsy and many others (http://www.goodoledays.weebly.com/benefits-of-goats milk.html).

Raw milk: It was established that the consumption of raw milk reduces total cholesterol level because of the higher presence of MCT, $36 \%$ in goat milk versus $21 \%$ in cow milk, which decreases the synthesis of endogenous cholesterol. It also helps to boost the immune system. Goat's milk alkalizes the digestive system and also helps to increase the $\mathrm{pH}$ level in the blood stream so prevents gastric ulcers [51].

Additionally, raw goat's milk fights microbes, primarily due to the healthy medium chained fatty acids it contains, such as capric and caprylic acids. It is very important to note that raw goat's milk is rich in selenium, a necessary bodily nutrient known for its immune strengthening and antioxidant properties and also goat's milk does not produce mucus; it does not stimulate a defense response from the human immune system. Raw goat's milk soothes (calm) the digestive tract; people with conditions, such as bloating, diarrhea, asthma, and irritability may very well be suffering from an allergic reaction to cow's milk (http://www. naturalnews.com/031586_raw_goats_milk_health.html).

Furthermore, goat's milk contains less of the enzyme xanthise oxidase. When it is entering the blood stream, this enzyme can cause tissue scar on the heart that result in the liver supplying more cholesterol in order to protect the heart. Arteriosclerosis can be the result of this mechanism, and homogenization of milk products has been linked to heart disease [51].

\section{Conclusion and Recommendations}

Recently, goat milk consumption and production increases globally as people recognize the advantage of goat milk especially in the developed nations. It is well known that goat milk has high nutritional value than other species of animals, where there is adequate browse and water supply and they are mainly raised in rangelands in semi deserts and sub tropic conditions. Goat has the ability to produce milk of good composition and quality for human consumption. These compositions of milk are fat, protein, ash, vitamins, lactose and enzymes. Although it is known that goat can produce milk which have high nutritional value and composition, various factors including breed, nutritional status, udder size and shape, body weight and litter size affect the composition and the contents of the milk. Different influencing factors that cause variation to the milk content are genetics, litter size, season, stage of lactation, parity, daily variation, type of diet, physiological status, udder health and physiological factors. Moreover, it also has medicinal value for human being and is healthy alternative to cow's milk that may be more easily digested than regular cow's milk, especially to children and those who have sensitive stomachs to other animals' milk. Goat milk lacks folic acid and it does not recommend for infants under one year because it can cause anemia. Goat milk also has a higher renal solute load compared to cow's milk and can place stress on an infant's kidneys. This milk has been found to cause metabolic acidosis and intestinal irritation when fed to infants in the first month of life.

From the above conclusion the following recommendations were forwarded:

- It is valuable to be aware of the factors that are affecting the composition and nutritional value of caprine milk as the composition is very important to human beings

- It is very important to be aware about the nutritional value of goat's milk

- Peoples should be aware of the health benefits of consuming goat milk

- The government should participate in the animal and human health care, and developing the sector goat production since it very important to improve the health of the population

- Studies should be conducted on impact of higher chlorine content of Goat milk for under one year infants.

\section{References}

1. Kris HK (2008) The history of domestication of goats. J Archaeolo Sci 28: 61-79.

2. Bagley MN (2006) Meat goat breeds, breeding management, and 4-H Market Goat Management. J Dairy Sci 28: 30-5.

3. Thornton PK (2010) Livestock production: Recent trends and future prospects. Philos Trans R Soc Lond B Biol Sci 365: $2853-67$.

4. Galal S (2005) Biodiversity in goats. Small Rumi Res 60: 75-81.

5. CSA (2008-2010) Annual Agricultural Sample Survey Reports, CSA of Ethiopia, 2-7.

6. Devendra C, McLeroy GB (1996) Goat and sheep production in the tropics. $7^{\text {th }}$ edn, Payne, W.J.A and Longman (ed.), London and New York Publishers, 1-55. 
7. Devendra C (1999) Goats: challenges for increased productivity and improved livelihoods. Outlook on Agriculture 28: 215-26.

8. Jenness R (1980) Composition and characteristics of goat milk: Review 1968-1979. J Dairy Sci 63: 1605-30.

9. Haenlein GF (2004) Past, present and future perspectives of small ruminant dairy research. J Dairy Sci 84: 2097-115.

10. Park YW (1994) Hypo-allergenic and therapeutic significance of goat milk. Small Rumi Res 14: 151-9.

11. Roy SK, Vadodaria VP (2006) Goat Milk and Its Importance. Indian Dairyman 58: 65-9.

12. Malau-Aduli BS, Eduvie IO, Lakpini CAM, Malau-Aduli, AEO (2001) Effects of supplementation on the milk yield of Red Sokoto does. Proceedings of the $26^{\text {th }}$ Annual Conference of Nigerian Society for Animal Production, March 2001, ABU, Zaria, Nigeria, 353-6.

13. Morgan D, Gunneberg C, Gunnell D, Healing TD, Lamerton S, et al. (2012) Medicinal properties of goat milk. J Dairy Goat 90: 1.

14. Haenlein GF (1992) Status and prospects of the dairy goat industry in the United States. J Anim Sci 74: 1173-81.

15. Park YW, Haenlein GFW (2006) Therapeutic and hypoallergenic values of goat milk and implication of food allergy. In. Y.W. Park and G.F.W. Haenlein. (eds): Handbook of Milk of Non bovine Mammals. Blackwell Publishing Professional, Oxford, England and Ames Iowa 121-36.

16. Ensminger RM, Parker O (2011) Sheep and goat science, $5^{\text {th }}$ ed. Parker College Mississippi College Cooper, Huddleston College, 265-7.

17. Peacock CP (1996) Improving goat production in the tropics. A Manual for Development Workers Practical Handbooks, $2^{\text {nd }}$ edn, Oxfam, FARM Africa, $308-12$. 18. Wholesaler T, Sahlu AL, Goetsch (2005) Small Rumi Res 60: 7-12.

19. Meinert TR, Korver S, Van Arendonk JAM (1989) Parameter estimation of milk yield and composition for 305 days and peak production. J Dairy Sci 72: $1534-9$.

20. Alawa JP, Oji UI (2008) Effect of pendulous udder enlargement on yield and proximate composition of milk from red Sokoto goats. J Anim Vet Adv 7: 870-2. 21. Milerski M, Mareš V (2001) Analysis of systematic factors affecting milk production in dairy goat. Acta Univ Agric E.T. Silvic Mendel Brun (Brno) 1: 43-50.

22. Zumbo A, Di Rosa R (2007) Effects of parity and type of kidding on the quantitative and qualitative milk characteristics of the Rossa Mediterranea goats, Italy. J Anim Sci 6: 636.

23. Zeng SS, Escobar EN, Popham T (1997) Daily variation in somatic cell count, composition and production of Alpine goat milk. Small Rumi Res 26: 253-60.

24. Butswat ISR, Mbap ST, Ayibatonye GA (2000) Heat tolerance of sheep in Bauchi, Nigeria. Tropi Agri (Trinidad) 77: 265-8.

25. Peeters R, Buys N, Robijns L, Vanmontfort D, Van Isterdael J (1992) Milk yield and milk composition of Flemish milk sheep, Suffolk and Texel ewes and their crossbreds. Small Rumi Res 7: 279-88.

26. Garry AW, Chritine M, Bruhn JM (2000) Reported adoption of dietary fat and finer recommendations among consumers. J Ame Dietetic Assoc 100: 52-8.

27. Bruhn CM, Schutz HG (1999) Consumer food safety knowledge and practices. J Food Safety 19: 73-87.

28. Ambrosoli R, Stasio LD, Mazzocco P (1988) Content of alpha-s1-casein and coagulation properties in goat milk. J Dairy Sci 71: 24-8.

29. Haenlein GFW (2002) Composition of goat milk and factors affecting it. Small Rumi Res 51: 155-63.

30. Montaldo HH, Manfredi E (2002) Organizations of selection programs for dairy goats. Proc $7^{\text {th }}$ World Congress on Genetics Applied to Livestock Production. Montpellier, France, 18: 71-94.

31. Thompson JR, Everett RW, Hammerschmidt NL (2000) Effects of inbreeding on production and survival in Holsteins. J Dairy Sci 83: 1856-64.

32. Barillet F (2007) Genetic improvement for diary production in sheep and goats. Small Rumi Res 70: 60-75.

33. Mukherjee TK (1992) Improvement of goats in the tropics through genetic and biotechnological methods. In: Pre-Conf. Proc V Int Conf on Goats, New Delhi, India, 26-36.

34. Kandarakis I, Moatsou G, Georgala A, Kaminarides S, Anifantakis E (2001) Effect of draining temperature on the biochemical characteristics of feta cheese. Food Chem 72: 369-78.

35. Simos E, Voutsinas LP, Pappas CP (1991) Composition of milk of native Greek goats in the region of Metsovo. Small Rumi Res 4: 47-60.

36. Haenlein GFW (1995) Topics of profitable feeding and milking of dairy goats. $4^{\text {th }}$ edn. Dept Animal Sci Agr Biochem Univ Delaware, Bulletin, 110-7.

37. Chilliard Y, Ferlay A, Rouel J, Lamberet G (2003) A review of nutritional and physiological factors affecting goat milk lipid synthesis and lipolysis. J Dairy Sci 86: $1751-70$.

38. Haenlein GFW (1993) Producing quality goat milk. J Anim Sci 8: 79-84.

39. Kifaro GC, Moshi NG, Minga UM (2009) Effect of sub-clinical mastitis on milk yield and composition of dairy goats in Tanzania. J Food Agric Nutr Dev 9: $623-34$.

40. O'Connor DL (1994) Folate in goat milk products with reference to other vitamins and minerals: A review. Small Rumi. Res 14: 143-9.

41. Schrander JJP, van den Bogart JPH, Forget PP, Schrander-Stumpel CTRM, Kuijten RH, et al. (1993) Cow's milk protein intolerance in infants under one year of age, a prospective epidemiological study. Europe J Pediatr 152: 640-4.

42. Andersson E, Draussin C (1993) Consumption of milk products by children 9-14 years old in the Paris area. Med E T Nutri 29: 115-21.

43. Browning JR, Leite-Browning ML, Sahlu T (1995) Factors affecting standardized milk and fat yields in Alpine goats. Small Rumi Res 18: 173-8.

44. Mourad M (1992) Effects of month of kidding, parity and litter size on milk yield of Alpine goats in Egypt. Small Rumi Res 8: 41-6.

45. Lu CD (1989) Effects of heat stress on goat production. Small Rumi Res 2: 151-62.

46. Tziboula-Clarke A (2003) Goat milk. Encyclopedia Dairy Sci 2: 1270-9.

47. Park YW (2006a) Goat milk-chemistry and nutrition. In: Park YW, Haenlein GFW (Eds), Handbook of Milk of Non-bovine Mammals. Blackwell Publishing Professional, Oxford, UK/Ames, Iowa, 34-58.

48. Razafindrakoto O, Ravelomanana N, Rasolofo A (1994) Goat's milk as a substitute for cow's milk in undernourished children: A randomized double-blind clinical trial. Pediatrics 94: 65-9.

49. Tracey JB (2001) Goat's milk for Infants. Health Options, Megazine.

50. Casoli C, Duranti E, Morbidini L, Panella F, Vizioli V (1989) Quantitative and compositional variations of Massese sheep milk by parity and stage of lactation. Small Rumi Res 2: 47-62. 
51. Alférez MJ, Barrionuevo M, López Aliaga I, Sanz-Sampelayo MR, Lisbona F, et al. (2001) Digestive utilization of goat and cow milk fat in malabsorption syndrome. J Dairy Res 68: 451-561.

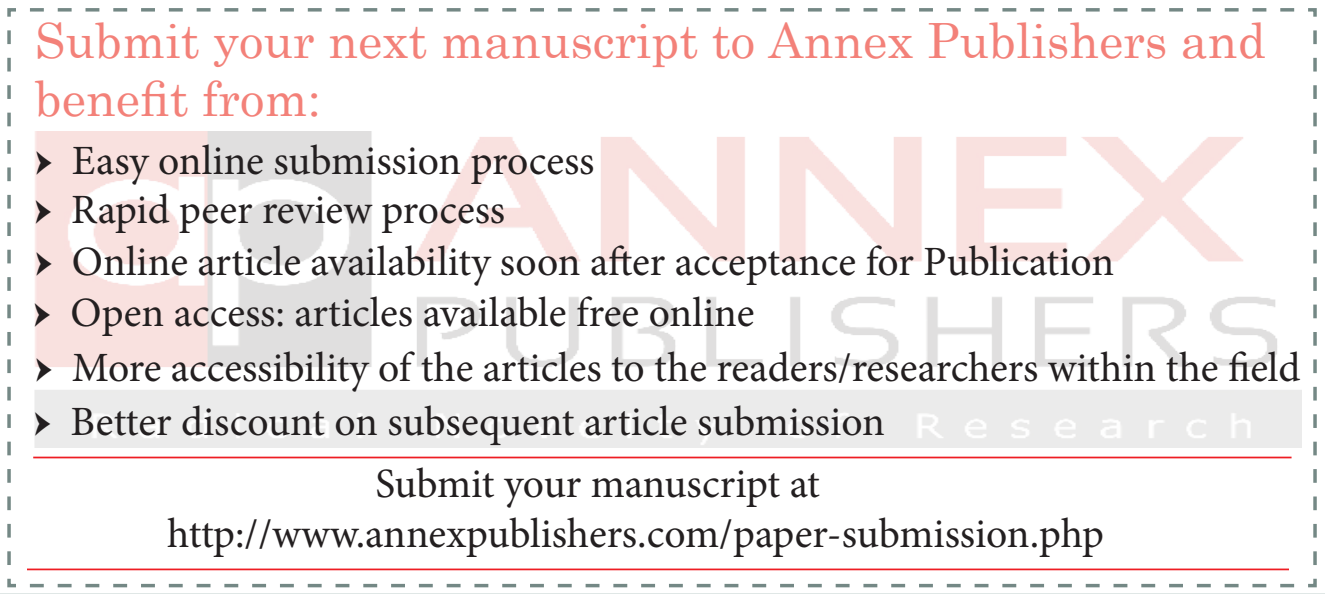

